\title{
Business Process Analysis For Marketing Honey Bee Products
}

\author{
$1^{\text {st }}$ Dede Rosyada ${ }^{1}, 2^{\text {nd }}$ Elpawati $^{2}, 3^{\text {rd }}$ Flori Ratna Sari $^{3}, 4^{\text {th }}$ Achmad Tjachja Nugraha $^{2}$, \\ $5^{\text {th }}$ Nida'ul Hasanati ${ }^{4}$ \\ \{dede.rosyada@uinjkt.ac.id¹, elpawati@uinjkt.ac.id², florirsari@uinjkt.ac.id ${ }^{3}$, \\ achmadtjahja@uinjkt.ac.id², nidaul.hasanati@uinjkt.ac.id $\left.{ }^{4}\right\}$ \\ Faculty of Tarbiyah and Education, UIN Syarif Hidayatullah Jakarta, Indonesia ${ }^{1}$, Department of \\ Agribusiness, Faculty of Science and Technology, UIN Syarif Hidayatullah Jakarta, Indonesia ${ }^{2}$, Faculty \\ of Medicine, UIN Syarif Hidayatullah Jakarta, Indonesia ${ }^{3}$, Department of Information System, UIN \\ Syarif Hidayatullah Jakarta, Indonesia ${ }^{4}$
}

\begin{abstract}
Bees are God's creatures that produce honey. Honey has natural properties for health. Allah also commands us to be able to use honey as a medicine. Bee cultivation has been done and honey has been produced. It takes facilities to market these products so that people can quickly feel the benefits. Information Technology (IT) and the Internet today are very possible to spread knowledge and empower this product to the public quickly. Improving the IT field is something that is very necessary. This paper discusses the benefits of honey bees in the Qur'an along with the use of ICT to market products from honey bees and also about how to analyze the business process of selling honey bee products through e-commerce by modeling business processes using BPMN. The research method consists of collecting data by studying literature, interviews and observations to the location of honey bee cultivations. The data obtained is analyzed and provides the results of a Business Process Modelling for honey bee products marketing through e-commerce technology.
\end{abstract}

Keywords: honey bee, marketing, e-commerce, business process analysis, BPA, business process modelling notation, BPMN

\section{Introduction}

Bees are God's creatures that produce honey. Many properties are produced by honey and God commands us to be able to use honey as a medicine, as the word of God in the Qur'an:

"And your Lord revealed to the bees:" Make nests in the hills, in wood trees, and in places made by human. " [QS. An-Nahl: 68] "Then eat from each (kind) of fruit and take the path of your Lord that has been facilitated (for you). From the belly of the bee comes a drink in various colors, in which there is a cure for humans. Verily in this is a sign of the greatness of God for those who think. "[Surat an-Nahl: 69]

There are also some traditions which explain the benefits of honey, including:

1) The Prophet Muhammad also affirmed the efficacy of honey in the hadith narrated by Bukhari: "Honey is a cure for all kinds of sickness and the Qur'an is a cure for all tangles of mind. 
2) "From Abu Hurairah, he said: The Messenger of Allah said:" Whoever licks honey three times a morning every month, then he will not be subjected to great trials. "

Honey is a natural product produced by stinging bees and stingless bees. Both types of bees produce honey with specific phenolic and flavonoid content which is very beneficial for human health [1].

It is an important thing to introduce a product or brand to a lot of people or buyers, therefore, marketing is something that must be really considered if you want to run an enterprise or business. Another important thing that must be remembered is that marketing is a constantly changing thing, so it is imperative to keep innovating [2].

This study only used a sample of bee cultivation site, namely the Rumah Kompos UIN Jakarta. In this place, the product produced from Trigona SP bee is propolis honey and bee pollen. In fact, there have not been many places to grow and also sell products from Trigona SP bee by the people in Indonesia. Honey produced is forest honey or sting honey as much as $75 \%$, and honey from stingless bee $25 \%$ [2]. For this reason, strategy concepts are needed that can expand the sales area of the Trigona SP bee, so that more consumers will know, and have an interest in using the results of this Trigona SP bee. In accordance with the advances in information and communication technology, the utilization of information technology is more effective because it can be accessed by suppliers, sellers and consumers easily.

This is a case study of a cultivation in the Compost House of Syarif Hidayatullah State Islamic University. This cultivation really needs fast marketing tools for products. There are still many stingless bee cultivations, such as in Yogyakarta, Sulawesi, Pandeglang, Banten and other regions in Indonesia. Therefore this paper discusses how to analyze a business process to market the honey bee products through e-commerce and make business process modeling with Business Process Modelling Notation (BPMN).

\section{Literature review}

The bee that is currently booming is cultivated is Trigona Stingless Bee. The bee is a stingless bee that is not dangerous and can be cultivated anywhere, both in large gardens and in the land around the house. Trigona cultivation allows for those who do not have large land. Trigona is the largest genus of bees without sting. Trigona is in the Neotropic region and also throughout the Indo-Australian region. There are about 150 species that belong to this genus, which distinguishes mainly from the hind legs. The Trigona Stingless Bee classification is as follows:

$\begin{array}{ll}\text { Kingdom: } & \underline{\text { Animalia }} \\ \text { Phylum: } & \underline{\text { Arthropoda }} \\ \text { Class: } & \underline{\text { Insecta }} \\ \text { Order: } & \underline{\text { Hymenoptera }} \\ \text { Superfamily: } & \underline{\text { Apoidea }} \\ \text { Family: } & \underline{\text { Apidae }} \\ \text { Subfamily: } & \underline{\text { Apinae }} \\ \text { Tribe: } & \underline{\text { Meliponini }}\end{array}$


Jurine, 1807

Stingless bee bees besides producing honey and propolis also have other benefits, namely as a pollinator. Stingless bees can become pollinators better than honeybee pollinators. Trigona SP stingless Bee can grow and develop around the house (yard, on house terraces, under the roofs of houses protected from rain. Trigona SP bee cultivation is much easier compared to Avis Mallivera (stinging bees) because it must be done with a system of angon (migratory beekeeping), that is bees grazed in a mobile manner following the flower season of plants [3].

The ministry of Forestry said that the indonesian farmer's honey production only reached 5.000 tons a year, far from the world's needs of 15.000 tons per year [4]. With a total population of around 250 million people and the assumption of honey per capita consumption in Indonesia of 30 grams / year we need at least 7,500 tons of honey per year to meet domestic honey needs. This deficiency of Indonesia must be imported every year more than $50 \%$ of national honey consumption needs.

The results of Berem's research [5] state that the need for an institutional analysis function and a sustainable long-term development framework to support the successful implementation of honey marketing. From the results of the regression analysis, it was found that the increase in the price of honey showed an increase in honey needs 8,417 times each year in Ethiopia [6]. Honey producers in Serbia show that the average production costs are the same. From the results of the study it was found that there was a direct marketing system, to increase the added value of direct contact with consumers. The strategy is carried out by reducing costs without seeing the number of logs held [7]. The marketing strategy for honey and other products is by increasing cooperation, cooperative investment, and increasing public awareness about cooperation [8].

Marketing (Marketing) is the process of preparing integrated communication that aims to provide information about goods or services in relation to satisfying human needs and desires [9].

Marketing mix is a set of marketing tools used by companies to achieve marketing objectives in the target market. E. Jerome McCarthy named the marketing tools "the four Ps of Marketing". The intended 4P is Product, Price, Promotion, and Place.[9]. McCarthy grouped the marketing mix activities into four groups known as 4P namely product, price, place and promotion. The $4 \mathrm{P}$ variable can be explained as follows [10].

E-commerce is a dynamic set of technologies, applications and business processes that connect certain companies, consumers and communities through electronics transactions and trade in goods, services and information which is done electronically. E-commerce / Electronic Commerce (e-business) is an activity business that is run (e.g. business transactions) electronically through a network (usually internet) and computer or buying and selling of goods or services (or transferring money) through digital communication channels [11].

By using e-commerce companies can obtain several benefits which include [11]:

1) Customer service and corporate image become good,

2) Find new business partners,

3) The process becomes simple and time can be compressed,

4) Increase productivity and access to information quickly,

5) Paper usage can be avoided, 
6) Transportation costs are reduced and flexibility increases.

7) Can serve 24-hour transactions at each location

8) Provide many choices to customers

9) Providing products that are not expensive and shipping is faster.

These are the two options for electronic trading (electronic commerce or eCommerce): Business-to-Consumer (B2C) and business-to-business (B2B). Business-to-consumer, is a process for selling products directly to consumers. B2B, which stands for business-tobusiness, is a process for selling products or services to other businesses. [12].

Vergidis et al. [13] state that however, business process analysis is a term used with a rather broad meaning including a range of different tactics such as simulation and diagnosis, verification, and performance analysis of business processes. Business process analysis aims at investigating properties of business processes that are neither obvious nor trivial [14].

Business process modeling plays a major role in the perception and understanding of business processes. In most of the cases, a business process is as expressive and as communicative as is the technique that has been used to model it. Therefore, the elements and the capabilities of a business process model play a significant role in describing and understanding a business process [13].

BPMN (Business Process Modeling Notation) is a relatively new methodology, but now it is widely accepted as a standard model to describe the business processes of an organization. BPMN does not only consist of model diagrams but also comes with a series of tools to reduce the process to become the language of business execution [15].

\section{Research Method}

This research method begin with literature study. In this step, researchers collected literatures, papers, and books from prior studies that discuss about Bee, especially for the Stingless Bee. Besides that, there are also topics and materials about information and communication technology including marketing with e-commerce. The next step is interviews, researchers asked some questions to the interviewees about the process of Stingless Bee cultivation and the honey production. The last step is observation. Observation is carried out the direct observations of the trigona bee cultivation process at the Compost House of UIN Jakarta. The results obtained are bee trigona culture can produce honey propilis and bee pollen.

After all the data needs are completed, researchers analyzing the data. Data analysis is a very important part in solving research problems, while answering hypotheses and achieving research objectives. The data that has been obtained is then processed by using an analytical tool, Microsoft Office. Data processing consists of data tabulation and data classification used. Tabulation is the compilation of data into table form. The results of the research data were analyzed using data tabulation and concluded descriptively. Data tabulation is the compilation of data into table form. The purpose of tabulation is so that data can be easily compiled, summed up and simplifies data arrangement to be presented and analyzed. The tabulation process can be done by the tally method, using a card, or using a computer [13]. While descriptive analysis is a method used to describe or analyze a research result but is not used to make broader conclusions [14]. 


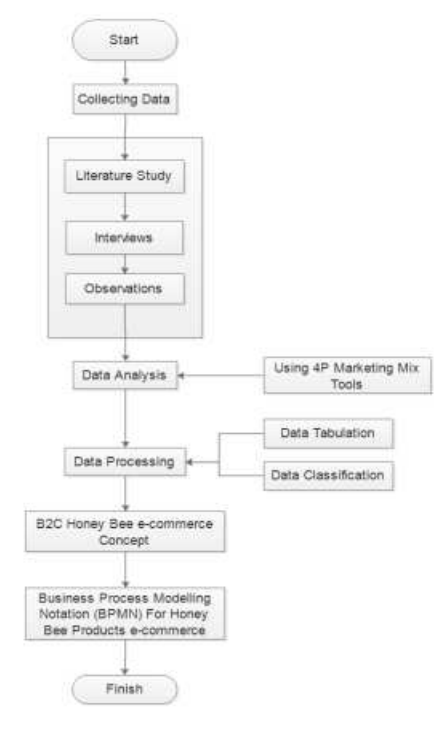

Fig. 1. Research Framework

\section{Result}

Bees are special creatures, created by God Almighty that provide benefits and enjoyments to humans. so that the activity of bee cultivation is a beneficial activity for human life. This is related to the implementation of bee trigona cultivation at the composting house of UIN Jakarta. In the cultivation activity in the compost house consists of several stages of the process such as making the stup, placing the colony log containing bees, maintenance, harvesting and postharvest.

The stages include the following: a) Stups are made of wooden planks measuring approximately $20 \times 15 \times 10 \mathrm{~cm}$. The use of this stup is to produce honey, propolis and bee pollen, making it easier to harvest. In addition, the benefits of making a stup that can avoid the dangers of pests such as ants, spiders, lizards and others. b) The placement of the colony logs is done neatly so that it is easier to control and clean the environment of the heterotrigona bee cultivation. The distance between the colony logs is around $1.5-2$ meters per colony log. c) Maintenance is carried out by controlling each log, planting flowering plants in each area of the bee cultivation environment, cleaning the area of cultivation so that it is not attacked by pests. d) Harvesting can be done every 3 months or 4 months using syringes or honey suction devices. The results of the benefits of bee trigona production which produce honey, propolis and bee pollen provide business opportunities for cultivation. The productivity of bee trigona products at Kompos UIN House is the amount of honey, propolis and bee pollen produced in one year. 


\begin{tabular}{|l|c|c|c|}
\hline Product Type & Production Result & Unit & Total Production per Bottle \\
\hline Honey & $15068 \mathrm{~mL}$ & $250 \mathrm{~mL}$ & 60 \\
\hline Propolis & 27189 grams & 250 grams & 109 \\
\hline Bee Pollen & 6956 grams & 250 grams & 28 \\
\hline \multicolumn{3}{|c|}{ Total } & $\mathbf{1 9 7}$ \\
\hline
\end{tabular}

Fig. 2. Result of Tabulation of Trigona Beekeeping Production. Results Per Year

Details of honey bee trigona products amounted to $15,068 \mathrm{~mL}$ or 60 bottles of $250 \mathrm{~mL}$ with selling price in the domestic market averaging Rp. 150,000, - and generate revenue of Rp. 9,000,000, - propolis products amounted to 27,189 grams or 109 bottles of 250 grams per bottle and the selling price in the domestic market is averaged Rp. 250,000, - and generate revenue of Rp. 27,250,000, - while the product amounted bee pollen to 6,956 grams or 28 bottles of 250 grams with a selling price of $\mathrm{Rp}$. 100,000, - and generate revenue of $\mathrm{Rp}$. $2,800,000$.

The largest amount of production produced by Bee Trigona at the Composite House of UIN Jakarta is the production of propolis compared to the production of honey and bee pollen. This is due to the lack of flower feed which produces nectar and pollen in the cultivation area. While foreign market participants benefit from the production of Bee trigona which produces honey and propolis, it provides business opportunities at this time, the wholesale market price of honey and propolis is around AU $\$ 50$ per $\mathrm{kg}$ in Asia, the stingless beekeeping for pollination is only beginning to take root in Asia South, India and in Southeast Asia including Malaysia and the Philippines [15].

The marketing concept of Trigona SP bee products based on the 4P Marketing Mix study offered is as follows:

1)Product

As previously explained, the Trigona SP Bee cultivation process carried out at the Compost House of UIN Jakarta consists of several stages, starting with the making of the stup, placing the colony log containing bees, maintenance, harvesting and postharvest. The cultivation process produces products namely honey, propolis and bee pollen.

2)Price

Prices are priced for each product produced by Trigona SP Bee based on the average selling price in the domestic market, for honey with a size of $250 \mathrm{~mL} /$ bottle for Rp 150,000 , propolis with a size of 250 grams / bottle for Rp 250,000, and for bee 250 gram / bottle pollen is worth $\mathrm{Rp} 100,000$. Within a period of one year, the Compost House of UIN Jakarta produced 60 bottles of honey, 109 bottles of propolis and 28 bottles of bee pollen so that the total revenue generated from the sale was Rp. $39,050,000$. 
3) Place

A place to market the products of Trigona SP Bee through e-commerce. This ecommerce system has a function as a platform for buying and selling online. The functions contained in this system include the function of product description, product prices, number of products available, selection of payment and shipping transactions. The actors involved in this system are: 1) the administrator of the system who manange the user of the e-commerce system, 2) sales division, 3) distribution division, 4) manager or excecutive or the leader of the Compost House of UIN Jakarta and 5) Customer. Customer can also be a consumer, the one who consumes the goods. The benefits of implementing an e-commerce system to market products include the broader range of product marketing areas and costumer can do transactions quickly and easily.

\section{4) Promotion}

marketing for Trigona SP Bee products can also be done through advertisements both on television, radio, and print media, for example advertising in newspapers, posting banners and distributing brochures in public places, and in the present way through social media such as Facebook, Twitter, Instagram, and others. Do not forget to include e-commerce web addresses so that consumers can easily find information about products and increase opportunities to make purchases.

The online sales process through e-commerce is modeled using Business Process Modeling Notation (BPMN). in this process, there are 4 actors involved, namely customers, sales division. distribution division, and executive. Customers are placed separately on one pool and the e-commerce system is placed in the pool lane with three functions, namely, the sales division. distribution division, and executive.

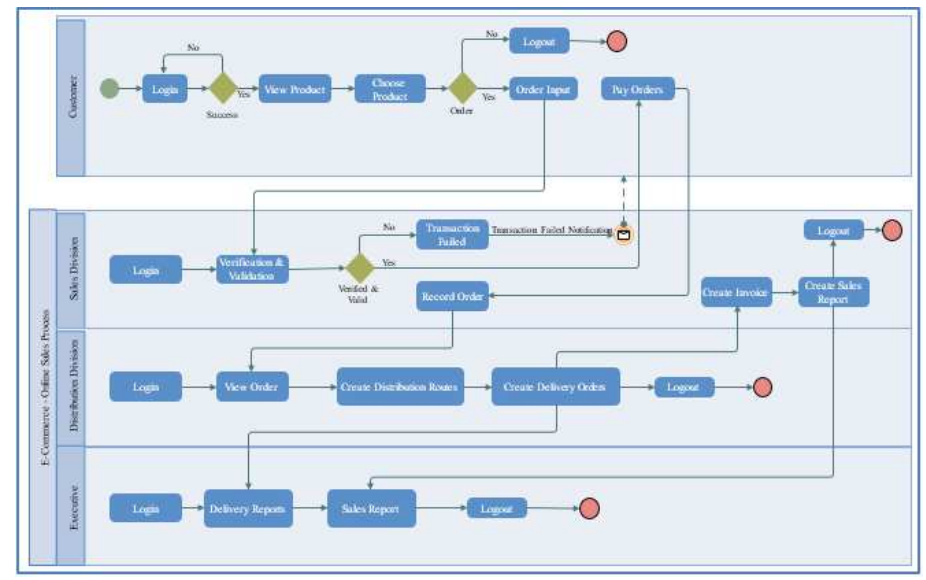

Fig.3. BPMN diagram of the E-Commerce Online sales process for Honey Bee Product

Figure 3 illustrates the sales process that starts from the customer who logs in and sees the product being sold, selects the product and then decides whether to buy the product or not. If a customer wants to buy a product, the process continues to the next stage, but if the customer does not buy, the customer can log out immediately. 
the next process after the customer decides to buy the product is that the customer enters the order, and the sales division will verify and validate the product ordered. If it is verified and validated, customers can make payments for their orders and the process continues. If the order made is not verified and validated, the sales division will provide a failed transaction notification.

After receiving payment from the customer, the sales division will record the order. Records of this order were then seen by the distribution division, and the distribution division made distribution routes and also made delivery of orders. Next, the sales division will make invoices and sales reports. this sales report which will later be seen by the executive. in addition, the executive will also see reports on the delivery orders made by the distribution division.

\section{Conclusion}

Marketing concepts using information and communication technology can be applied to market products produced by Trigona SP Bee. This study generate the Business to consumer (B2C) Honey Bee e-commerce concept using the 4P Marketing Mix approach. Due to the sample limitations used in this study which only amounted to one sample, namely bee cultivation at the Compost House UIN Jakarta, the number of products that can be marketed using this marketing concept is not much.

The analysis of the business process of selling honey bee products is modeled with Business Process Modelling Notation (BPMN). BPMN can be used to model the sales process on e-commerce system of honey bee products in a simple and comprehensive manner. For the case study used in this paper, there are 4 actors involved in the e-commerce system, namely customers, sales division, distribution division, and executive. For further research it may be able to involve more actors and a more detailed process and it is expected to be able to use more and varied samples so that the application of this concept can be maximized.

Acknowladgement. This paper in conjuction with International Conference on Science and Technology, Bangunan Pejabat Timbalan Naib Canselir (Penyelidikan dan Inovasi), Universiti Putra Malaya Selangor, Malaysia.

\section{References}

[1] Rao Pasupuleti, Krishnan Kumara Tevan, Salleh Naguib, Gan Siew Hua. Biological and Therapeutic effect of Honey produced by Honey Bees and Stingless Bees. Revista Brasileira de Farmacognosia.Volume 26.Issue 5, pp. 657-664, 2016.

[2] Novandra, Alex; Widnyana, I. M. Peluang pasar produk perlebahan Indonesia. Departemen Kehutanan: Balai Peneltian Teknologi Hasil Hutan Bukan Kayu, 2013.

[3] Saepudin Rustam. Identifikasi Permasalahan Perlebahan sebagai Dasar Pengembangan Usaha Madu di Propinsi Bengkulu. Journal Sain Pertanian Indonesia. Vol.10.No.1. Hal 51-52.ISSN 19783000, 2015.

[4] Produksi Madu Indonesia 5.000 Ton Setahun [Online]. Available at https://www.antaranews.com/berita/458883/produksi-madu-indonesia-5000-ton-setahun. 2014 
[5] Berem Risper M.. Economic Analysis of Honey Production and Marketing in Bringo County, Kenya, An Aplication of the Instittutional Analysys And Development Framework. Journal Of atural Science. Risearch. 2-ISSN 2225-0921.Vol.5. No.10. pp 34-41, 2015.

[6] Heilemariam Atsbaha dan Tolemariam Taye. 2017. Assesment of honey Marketing System and Its Value Chain In Trhee Selected Woredas Of Tigray Region, Ethiopia. Journal Of marketing and Consumer Research. ISSN 2422-8451 An International Peer-Reviewed Journal.Vol.35.Hal 37-47

[7] Zaric Vlade, Vasiljevic Zorica, Nedie Nebojsa, Petkovic Danijela. 2012. The Marketing Strategis Of Serbian Honey Producers. Agroinform Publishing House, Budapest. Hal 27-31

[8] Saner Gamze, Engindeniz Sait, Yercan Murat, Karaturhan Buket. 2007.Alternative Marketing Strategies For Honey and Other Bee Product In Turkey. Journal Agriculture and Food Information. Do:10.1080/10496500802083690.Hal 64-74

[9] Rachmawati Rina, 2011. Peranan Bauran Pemasaran (Marketing Mix) terhadap Peningkatan Penjualan (Sebuah Kajian terhadap Bisnis Restoran) Jurnal Kompetensi Teknik Vol. 2, No. 2, Mei 2011

[10] Sefudin Akhmad. Redefinisi Bauran Pemasaran (Marketing Mix)“4p” Ke "4c"(Studi Kasus Pada Universitas Indraprasta PGRI). JABE (Journal of Applied Business and Economic), 2017, 1.1: 17-23.

[11] Medah, M. (2009). E-commerce Sebagai Pendukung Pemasaran Perusahaan. Partner, 16(1), 74-81.

[12] Meier, Andreas, and Henrik Stormer. eBusiness \& eCommerce: managing the digital value chain. Springer Science \& Business Media, 2009.

[13] Vergidis, Kostas, Ashutosh Tiwari, and Basim Majeed. "Business process analysis and optimization: Beyond reengineering." IEEE Transactions on Systems, Man, and Cybernetics, Part C (Applications and Reviews) 38.1 (2008): 69-82.

[14] W. M. P. van der Aalst, A. H. M. ter Hofstede, and M. Weske, "Business process management: A survey," in Lecture Notes Computer Sciences Springer-Verlag, 2003, vol. 2678, pp. $1-12$.

[15] Rosmala, Dewi, et al. Pemodelan Proses Bisnis B2B dengan BPMN (Studi Kasus Pengadaan Barang pada Divisi Logistik). 2007. 